\title{
DETERMINAN KEJADIAN COMPOSITE INDEX OF ANTHROPOMETRIC FAILURE (CIAF) DI KABUPATEN SIJUNJUNG, PADANG PARIAMAN DAN PASAMAN BARAT
}

\author{
Refliny Yulia Fitri ${ }^{1}$, Neila Sulung ${ }^{2}$, Sukarsi Rusti ${ }^{3}$ \\ Sekolah Tinggi Ilmu Kesehatan Fort De Kock, Jalan.Soekarno Hatta, Kelurahan Manggis Gantiang Kecamatan \\ Mandiangin Koto Selayang, Bukittinggi \\ email: refliny@gmail.com
}

Submitted: 20-10-2018, Reviewer: 05-12-2018, Accepted: 25-01-2019

\begin{abstract}
Composite Index Of Anthropometric (CIAF) is a tool to measure nutrition, especially to identify children with several anthropometric failures. From WHO data estimates 52 million children under 5 years are thin, 17 million people are very thin and 155 million are short, while 41 million people are obese. About $45 \%$ of deaths among children under 5 years of age are related to malnutrition. The aim of the study was to determine the incidence of Composite Index of Anthropometric (CIAF) at the age of 24-59 months in Sijunjung District, Padang Pariaman and West Pasaman. This type of research is quantitative with Cross Sectional research design conducted in May-August 2018. The research population amounted to 9,164 children from three districts namely Sijunjung District, Padang Pariaman and West Pasaman. Samples in the study of children aged 24-59 months with a total of 267 children. The analysis used is univariate, bivariate and multivariate analysis. The results of this study using logistic regression for the most dominant factors influencing the CIAF event, namely the family economy with $P$ value 0,000 (OR 10,503).The conclusion of this study is that of the three districts that influence the incidence of CIAF are the maternal education and family economy.
\end{abstract}

Keywords : Composite Index of Anthropometric Failure (CIAF), Food Diversity and Environmental Health

\begin{abstract}
ABSTRAK
Composite Index Of Anthropometric (CIAF) adalah sebagai alat untuk mengukur gizi, terutama untuk mengidentifikasi anak dengan beberapa kegagalan antropometri. Dari data WHO memperkirakan 52 juta anak dibawah 5 tahun kurus, 17 juta orang sangat kurus dan 155 juta pendek, sementara 41 juta orang mengalami obesitas. Sekitar 45\% kematian diantara anak-anak dibawah usia 5 tahun terkait dengan kekurangan gizi. Tujuan penelitian untuk mengetahui kejadian Composite Index of Anthropometric (CIAF) pada usia 24-59 bulan di Kabupaten Sijunjung, Padang Pariaman dan Pasaman Barat. Jenis penelitian ini adalah kuantitatif dengan desain penelitian Cross Sectional dilakukan pada bulan Mei-Agustus 2018. Populasi penelitian berjumlah 9.164 anak dari tiga kabupaten yaitu Kabupaten Sijunjung, Padang Pariaman dan Pasaman Barat. Sampel dalam penelitian anak usia 24-59 bulan dengan jumlah 267 anak. Analisa yang digunakan adalah analisa univariat, bivariat dan multivariat. Hasil penelitian dengan menggunakan regression logistic untuk faktor yang paling dominan mempengaruhi kejadian CIAF yaitu ekonomi keluarga dengan P value 0,000 ( OR 10,503). Kesimpulan dari penelitian ini adalah dari ketiga kabupaten yang mempengaruhi kejadian CIAF adalah pendidikan ibu dan ekonomi keluarga.
\end{abstract}

Kata Kunci : Composite Index Of Anthropometric Failure (CIAF), Keragaman Makanan dan Kesehatan Lingkungan 


\section{PENDAHULUAN}

Masalah gizi pada dasarnya merupakan refleksi konsumsi zat gizi yang belum mencukupi kebutuhan tubuh. Seseorang akan mempunyai status gizi baik apabila asupan gizi sesuai dengan kebutuhan tubuh. Asupan gizi yang kurang akan dapat menyebabkan kasus kekurangan gizi, sebaliknya orang yang asupan gizi berlebih dapat menyebabkan gizi berlebih. Gizi kurang, berlebih dan gizi buruk yang terus-terusan terjadi akan dapat menghambat dalam pertumbuhan dan perkembangan yang akan berakibat dalam pembangunan nasional. Masalah gizi harus dapat perhatian serius akan mempengaruhi kualitas bangsa, ibu yang pendek juga terbukti melahirkan $46,7 \%$ bayi pendek (Bapenas, 2013).

Composite Index of Anthropometric (CIAF) telah dilaksanakan untuk mengukur prevalensi kekurangan gizi dengan menyajikan gambaran Indeks komposit kegagalan antropometri secara lebih lengkap dibandingkan dengan indeks konvensional (Endris, Asefa,\& Dube, 2017).

World Health Organization (WHO) bertujuan untuk membebaskan dunia dari kekurangan gizi, dimana semua orang mencapai kesehatan dan kesejahteraan menurut strategi gizi 2016-2025, WHO bekerja dengan negara-negara dan bermitra untuk mendapatkan akses universal terhadap interfensi nutrisi yang efektif dan pola makan sehat dari sistem makanan yang kelanjutan secara global. WHO memperkirakan 52 juta anak dibawah 5 tahun kurus, 17 juta orang sangat kurus dan 155 juta pendek, sementara 41 juta orang kelebihan berat badan atau obesitas. Sekitar $45 \%$ kematian diantara anakanak dibawah usia 5 tahun terkait dengan kekurangan gizi.

Hasil Riskesdas dari tahun 2007 ke tahun 2013 menunjukkan fakta yang memprihatinkan di Indonesia dimana underweight meningkat dari $18,4 \%$ menjadi $19,6 \%$, stunting juga meningkat dari $36,8 \%$ menjadi $37,2 \%$, sementara wasting (kurus) menurun dari $13,6 \%$ menjadi 12,1\%. Berdasarkan Riskesdas 2013 di Sumatera Barat prevalensi wasting 12,6\%, stunting 39,2\%, dan underweight 21,2 \% (Kemenkes RI, 2015).

Masalah Gizi Balita di Provinsi Sumatera Barat Tahun 2016 pada anak usia 24-59 bulan dari 19 Kabupaten/Kota Kabupaten yang akan diteliti ada pada urutan empat yaitu Kabupaten Sijunjung 13,02\%, urutan ke lima Kabupaten Padang Pariaman 13,1\%, urutan ke enam Kabupaten Pasaman Barat.

Pada survey awal Wilayah kerja Puskesmas Kumanis di Kabupaten Sijunjung dengan 15 responden dengan ibu yang memiliki anak usia 24-59 bulan di dapatkan angka permasalahan gizi gabungan Composite Index of Anthropometric Failure (CIAF) adalah pendek-kurus $66,6 \%$, pendek-normal $13,3 \%$, pendek-gemuk $13,3 \%$, dan gemuknormal 6,6\%. Di dapat dari survai awal mengenai permasalahan variabel independen yang ditemukan $53,3 \%$ responden mengalami permasalahan keragaman makanan, 46,6\% responden mengalami permasalahan dalam pemberian makanan dan $60 \%$ responden mengalami permasalahan dalam lingkungan.

Tujuan pada penelitian ini adalah untuk mendapatkan Determinan Kejadian Composite Index of Anthropometric Failure (CIAF) Pada Anak Usia 24-59 Bulan Di Kabupaten Sijunjung, Padang Pariaman, dan Pasaman Barat tahun 2018.

\section{METODE PENELITIAN}

Penelitian ini untuk mengetahui pengaruh keragaman makanan, pemberian makanan dan kesehatan lingkungan terhadap Kejadian Composite Index of Anthropometric Feilure (CIAF) dengan variabel covariat yaitu umur, jenis kelamin, pendidikan ibu dan ekonomi keluarga.

Penelitian ini telah dilaksanakan pada bulan Mei sampai dengan bulan Agustus tahun 2018 di wilayah kerja Puskesmas Kabupaten Sijunjung, Padang Pariaman, dan Pasaman Barat. Penelitian ini telah dilakukan di 3 
kabupaten tertinggi yang diwakili oleh 2 puskesmas pada masing-masing kabupaten diantaranya Kabupaten Sijunjung yaitu di Puskesmas Tanjung Ampulu dan Puskesmas Kumanis, Kabupaten Padang Pariaman yaitu Puskesmas Pasar Usang dan Puskesmas Sungai Limau dan Kabupaten Pasaman Barat yaitu Puskesmas IV Koto Kinali Dan Puskesmas Kajai. Sampel yang digunakan dalam penelitian ini adalah anak-anak balita usia 24 bulan- 59 bulan yang berada di wilayah kerja Puskesmas serta memenuhi kriteria penerimaan (inklusi).

Penentuan sampel penelitian menggunakan teknik sampel Multistage Random Sampling yaitu pemilihan sampel secara acak setiap orang dalam kerangka sampling memiliki probabilitas yang sama dipilih. Populasi pada penelitian ini berjumlah 9.164 anak balita yang berusia 24-59 bulan dari 3 Kabupaten dengan diPopulasi di Kabuapten Sijunjung dengan populasi 4.241 dengan terpilih Puskesmas Tanjung Ampulu dengan populasi 3.038 dan Puskesmas Kumanis dengan populasi 1.203, pada Kabupaten Padang Pariaman dengan jumlah populasi 4.384 dengan terpilihnya Puskesmas Pasar Usang dengan 2.160 populasi dan Puskesmas Sungai Limau dengan 2.224 populasi dan pada Kabupaten Pasaman Barat dengan diwakili Puskesmas IV Koto Kinali dengan 300 populasi dan Puskesmas kajai dengan 239 populasi.

Dari 19 Kabupaten yang ada di Sumatera Barat diambil peringkat 4-6 untuk dijadikan tempat penelitian yaitu Sijunjung, Padang Pariaman, dan Pasaman Barat. Penelitian ini menggunakan desain penelitian kuantitatif dengan pendekatan cross sectional. Menggunakan data sekunder yang diperoleh dari petugas puskesmas dan data primer yang di peroleh dari kuesioner dengan teknik pengambilan sampel secara multistage rendom sampling.

Tabel 1

Pengaruh Composite Index Of Anthropometric Failure (CIAF) dengan Keragaman Makanan, Pemberian Makanan, Kesehatan Lingkungan, Umur, Jenis Kelamin, Pendidikan Ibu, dan Ekonomi Keluarga di Kabupaten, Sijunjung, Padang Pariaman dan Pasaman Barat Tahun 2018

\begin{tabular}{|c|c|c|c|c|c|c|c|c|}
\hline \multirow[b]{2}{*}{ Variabel } & \multicolumn{2}{|c|}{ CIAF } & \multicolumn{2}{|c|}{ Tidak CIAF } & \multicolumn{2}{|c|}{ Jumlah } & \multirow{2}{*}{$\begin{array}{c}\mathrm{P} \\
\text { Value }\end{array}$} & \multirow[t]{2}{*}{ OR } \\
\hline & $\mathrm{n}$ & $\%$ & $\mathrm{~N}$ & $\%$ & $\mathrm{n}$ & $\%$ & & \\
\hline \multicolumn{9}{|l|}{ Umur } \\
\hline Berisiko & 40 & $16,3 \%$ & 206 & $83,7 \%$ & 246 & $100 \%$ & \multirow{3}{*}{0,616} & \multirow{3}{*}{1,845} \\
\hline Tidak Berisiko & 2 & $9,5 \%$ & 19 & $90,5 \%$ & 21 & $100 \%$ & & \\
\hline Jumlah & 42 & $15,7 \%$ & 225 & $84,3 \%$ & 267 & $100 \%$ & & \\
\hline \multicolumn{9}{|l|}{ Jenis Kelamin } \\
\hline Laki-Laki & 22 & $15,5 \%$ & 120 & $84,5 \%$ & 142 & $100 \%$ & \multirow{3}{*}{1,000} & \multirow{3}{*}{0,962} \\
\hline Perempuan & 20 & $16,1 \%$ & 105 & $83,9 \%$ & 125 & $100 \%$ & & \\
\hline Jumlah & 42 & $15,8 \%$ & 224 & $84,2 \%$ & 267 & $100 \%$ & & \\
\hline \multicolumn{9}{|l|}{ Pendidikan } \\
\hline Rendah & 35 & $27,8 \%$ & 91 & $72,2 \%$ & 126 & $100 \%$ & \multirow{3}{*}{0,000} & \multirow{3}{*}{7,363} \\
\hline Tinggi & 7 & $5 \%$ & 134 & $95 \%$ & 141 & $100 \%$ & & \\
\hline Jumlah & 42 & $15,7 \%$ & 225 & $84,3 \%$ & 267 & $100 \%$ & & \\
\hline \multicolumn{9}{|c|}{ Ekonomi Keluarga } \\
\hline Rendah & 37 & $28,5 \%$ & 93 & $71,5 \%$ & 130 & $100 \%$ & \multirow{3}{*}{0,000} & \multirow{3}{*}{10,503} \\
\hline Tinggi & 5 & $3,6 \%$ & 132 & $96,4 \%$ & 137 & $100 \%$ & & \\
\hline Jumlah & 42 & $15,7 \%$ & 225 & $84,3 \%$ & 267 & $100 \%$ & & \\
\hline
\end{tabular}


HASIL PENELITIAN

A. Analisis Bivariat Gabungan Kabupaten Sijunjung, Padang Pariaman dan Pasaman Barat

Berdasarkan tabel 1 dari 267 responden yang memiliki hubungan yang signifikan di antaranya Pendidikan dengan Pvalue 0,000 (OR 7,363) dan ekonomi keluarga dengan $\mathrm{P}$ value 0,000 (OR 10,503) artinya adanya pengaruh composite index of anthropometric failure (ciaf) dengan pendidikan ibu, dan ekonomi keluarga.

B. Mulivariat Gabungan antara Kabupaten Sijunjung, Padang Pariaman dan Pasaman Barat

Berdasarkan tabel 2 didapatkan dari beberapa variabel pendidikan ibu dan ekonomi keluarga. variabel yang paling dominan dari tiga Kabupaten yaitu Sijunjung, Padang Pariaman Dan Pasaman Barat yaitu variabel ekonomi keluarga.
PEMBAHASAN

\section{A. Pembahasan Hasil Analisis Bivariat} Pengaruh Composite Index of
Anthropometric Failure (CIAF) Dengan
Umur

Penelitian yang dilakukan di Kabupaten Sijunjung, Padang Pariaman dan Pasaman Barat Umur yang tidak beresiko 21 responden yang mengalami CIAF 9,5\% dengan $\mathrm{P}$ value 0,616 yang artinya tidak ada pengaruh antara CIAF dengan umur .

Pada umur 2-5 tahun anak sudah mulai bisa meminta sesuatu, termasuk meminta makanan yang dia inginkan seperti meminta makan, minum susu atau makanan lain yang disukai. Maka dalam membiasakan pola makan yang baik dan benar pada anak balita sebaiknya mendapat perhatian utama dari orangtuanya, agar anak tidak mengalami defisit energi dan protein (Prihatimi, 2011).

Anak Usia 3-5 tahun merupakan tahapan dimana anak mengalami tumbuh kembang dan aktivitas yang pesat sehingga

Tabel 2

Faktor yang Paling Dominan Mempengaruhi Composite Index of Anthropometric Failure (CIAF) di Kabupaten Sijunjung, Padang Pariaman dan Pasaman Barat

\begin{tabular}{|c|c|c|c|}
\hline & Variable & $\begin{array}{c}\text { Change in -2 } \\
\text { Log } \\
\text { Likelihood }\end{array}$ & Sig. \\
\hline \multirow[t]{4}{*}{ Step 1} & Umur & 1,033 & 0,309 \\
\hline & Jenis kelamin & 0,020 & 0,887 \\
\hline & Pendidikan Ibu & 6,407 & 0,011 \\
\hline & Ekonomi keluarga & 12,673 & 0,000 \\
\hline \multirow[t]{3}{*}{ Step 2} & Umur & 1,032 & 0,310 \\
\hline & Pendidikan Ibu & 6,388 & 0,011 \\
\hline & Ekonomi Keluarga & 12,689 & 0,000 \\
\hline \multirow[t]{2}{*}{ Step 3} & PendidikanIbu & 6,123 & 0,013 \\
\hline & Ekonomi & 12,494 & 0,000 \\
\hline
\end{tabular}


asupan nutrisi akan meningkat. Anak di usia ini masih bergantung pada orang tua dalam hal pemberian makan, anak sudah bisa memilih makanan yang disukainya. Peran orang tua sangat menentukan asupan nutrisi pada anak, asupan nutrisi yang tidak sesuai akan menyebabkan anak kekurangan gizi (Perdani, et al 2016).

Penelitian yang dilakukan $\mathrm{K}$,bell et all (2018) Anak berusia 1-5 tahun hasil uji menunjukan ada hubungan yang signifikan antara umur dengan pola makanan ( $\beta=$ 0,23; 95\% CI 0,04-0,20 p =0,004) tetapi penelitian ini tak sejalan dengan Penelitian yang dilakukan Ningrum, dkk (2017) yang berjudul hubungan antara status gizi stunting dan perkembangan balita usia 1259 bulan dengan hasil $(\mathrm{p}=0,307)$ penelitian ini menunjukkan tidak didapatkan hubungan antara usia dengan perkembangan balita.

Menurut peneliti perbedaan umur setiap anak kebutuhan yang di butuhkan berbeda dan cara pemberiannya menjadi berberbda karna di saat anak berumur 24 bulan sampai 59 bulan dalam mengkonsumsi makanan mereka sudah bisa menolak dan meminta makanan yang cenderung mereka sukai, maka dari itu peran ibu sangat dibutuhkan dalam mengatasi kesulitan anak yang suka memilih makanan atau menghindari bosan.

\section{Pengaruh Composite Index of Anthropometric Failure (CIAF) Dengan Jenis Kelamin}

Dari Kabupaten Sijunjung, Padang Pariaman dan Pasaman Barat jenis kelamin laki-laki 142 responden yang mengalami CIAF $15,5 \%$ didapatkan $P$ value 1,000 yang artinya tidak ada pengaruh antara jenis kelamin dengan CIAF.

Kebutuhan anak laki-laki lebih banyak membutuhkan zat protein dan tenaga ketimbang anak perempuan, serta dapat dilihat dari aktifitas yang dilakukan oleh anak laki-laki dan perempuan (Andriyani \& Wirjatmmadi, 2014).

Dalam penelitian Goswami (2016) di dapatkan Prevalensi kurang gizi diamati pada anak perempuan dan laki-laki pada usia 2-5 tahun usia dan jenis kelamin, Perbedaan usia yang signifikan diamati antara anak laki-laki dan perempuan pada underweight ( $p$ 0,05). Penelitian tidak sejalan dengan penelitian yang dilakukan Ningrum, et al (2017) yang berjudul hubungan antara status gizi stunting dan perkembangan balita usia 12-59 bulan dengan hasil penelitian ini menunjukkan tidak ada hubungan antara jenis kelamin dengan perkembangan balita.

Menurut peneliti perbedaan jenis kelamin antara laki-laki dan perempuan memiliki kebutuhan nutrisi yang berbeda karna dari aktivitas yang dilakukan berbeda membuat kebutuhan anak menjadi berbeda di karenakan aktivitas laki-laki lebih besar membuat kebutuhan nutrisi menjadi lebih banyak dibandingkan anak perempuan bila tidak terpenuhi resiko anak laki-laki untuk mengalami Composite Index of Anthropometric Failure (CIAF) lebih besar.

\section{Pengaruh Composite Index of Anthropometric Failure (CIAF) Dengan Pendidikan Ibu}

Dari tiga Kabupaten yang diteliti yaitu Kabupaten Sijunjung, Padang Pariaman dan Pasaman Barat Pendidikan ibu yang rendah 126 responden yang mengalami CIAF $27,8 \%$ dan pendidikan ibu yang tinggi 141 responden yang mengalami CIAF 5\% dengan $\mathrm{P}$ value 0,000 yang artinya ada pengaruh antara CIAF dengan pendidikan ibu didapatkan nilai OR 7,363 yang artinya pendidikan ibu yang rendah mengalami CIAF beresiko 7 kali lipat dari pada ibu pendidikan tinggi.

Tingkat pendidikan seseorang akan berkaitan erat dengan wawasan pengetahuan mengenai sumber gizi dan jenis makanan 
yang baik untuk konsumsi keluarga. Ibu rumah tangga yang berpendidikan akan cenderung memilih makanan yang lebih dalam mutu dan jumlahnya, dibanding dengan ibu yang pendidikannya lebih rendah. Bila pendidikan yang kurang baik pengetahuan seorang ibu yang kurang akan membuat kebutuhan tubuh keluarga yang bergizi dalam kehidupan sehari-hari makanan yang akan di sediakan seadanya saja. Pengetahuan memiliki peran penting dalam menentukan asupan makanan. Tingkat pengetahuan tinggi akan berpengaruh terhadap prilaku dalam memilih makanan yang akan berdampak pada asupan gizi. (Andriyani \& Wirjatmmadi, 2014).

Penelitian yang dilakukan Jannah, et al (2014) di dapatkan Hasil uji statistik kendall tau = 0,386 dengan signifikan 0,001, jadi Ho ditolak dan $\mathrm{Ha}$ diterima kesimpulan dalam penelitian ini adalah ada hubungan tingkat pendidikan ibu dengan status gizi balita, Tetapi penelitian yang dilakukan tidak sejalan yang dilakukan oleh oktaviana (2015) dengan Perhitungan exactfisher test menunjukkan nilai exact sig (2-sided) 0.500 dengan tingkatan kemaknaan 0.05 yang artinya $0.500>0.05$ bearti Ho di terima. Tidak ada hubungan tingkat pendidikan ibu dengan status gizi pada balita di Posyandu Desa Sebani Kecamatan Pandaan Kabupaten Pasuruan Tahun 2015.

Menurut peneliti di tiga kabupaten seorang ibu berpendidikan rendah akan cenderung lebih mudah memilih makanan yang lebih bergizi untuk di konsumsi oleh keluarganya, dibanding dengan ibu yang pendidikannya lebih rendah. Tinggi rendahnya pendidikan ibu akan menentukan atau mempengaruhi mudah tidaknya seseorang menerima suatu pengetahuan, semakin tinggi pendidikan maka seseorang akan lebih mudah menerima informasiinformasi gizi. Tetapi bila bukan faktor pendidikan ibu yang menjadi faktor yang mempengaruhi gizi anak balita ada faktor lain yang mempengaruhi status gizi anak balita salah satunya yaitu motivasi ibu untuk memberikan asumsi makanan yang bergizi dan pengetahuan ibu tentang penting nya makanan bergizi bagi anak balita.

\section{Pengaruh Composite Index of Anthropometric Failure (CIAF) Dengan Ekonomi Keluarga}

Di Kabupaten Sijunjung, Padang Pariaman dan Pasaman Barat ekonomi keluarga yang rendah 130 responden yang mengalami CIAF $28,5 \%$ dengan $\mathrm{P}$ value 0,000 yang artinya ada pengaruh antara CIAF dengan ekonomi keluarga didapatkan nilai OR 10,50 yang artinya 10 kali beresiko mengalami CIAF bila ekonomi keluarga yang rendah.

Pada umumnya pendapatan naik jumlah dan jenis makanan akan membaik. Akan tetapi, mutu makanan tidak selalu membaik. Hal ini disebabkan oleh karena peningkatan pendapatan yang diperbolehkan tidak digunakan untuk membeli pangan atau bahan makanan yang bergizi tinggi. Penelitian yang dilakukan M Ardian et al tahun 2016 di semarang dengan judul Determinan kejadian stunting pada bayi usia 6 bulan di kota semarang didapatkan hasil bahwa terdapat hubungan kejadian stunting antara status ekonomi keluarga dengan $\mathrm{p}=0,001$.

Penelitian yang dilakukan Arum, Rizki et al (2017) dengan Hasil analisis bivariat dengan melakukan uji hubungan menggunakan chi-square diperoleh nilai IK $95 \%$ CI $=0,466-3,786$ dan OR $=1,329$ yang menunjukkan bahwa tidak ada hubungan status ekonomi keluarga dengan status gizi kurang dan gizi baik, serta status ekonomi keluarga bukan faktor risiko.

Menurut peneliti di Kabupaten sijunjung ekonomi keluarga yang rendah akan membuat daya beli bahan pangan dalam keluarga menjadi sulit terdapat 
ekonomi keluarga yang tinggi tetapi tidak dapat memenuhi kebutuhan disebabkan Salah satunya jumlah keluarga yang banyak mengakibatkan ketidak cukupan dalam hal daya beli pangan yang bergizi atau uang yang digunakan untuk memberikan makanan yang baik untuk anak balita kemudian Kabupaten Padang Pariaman Jumlah anggota yang banyak untuk di penuhi kebutuhan walaupun ekonomi keluarga yang tinggi tetapi bila biaya kebutuhan yang harus di keluarkan banyak (kreditan kendaraan, kontrakan rumah) tetap saja akan menyebabkan daya beli konsumsipun akan kurang dan di Kabupaten Pasaman Barat kebutuhan yang banyak yang harus di penuhi tetapi pendapatan tidak mencukupi. Ekonomi kelurga bukan salah satu faktor yang status gizi yang baik dapat terpenuhi tetapi Tingkat pendidikan akan mempengaruhi jenis pekerjaan yang akan dimiliki dan akan berimbas pada jumlah pendapatan. Tingkat pendidikan baik akan membuat peluang yang lebih besar untuk mendapatkan pekerjaan yang semakin baik dimana pendapatan yang akan diperoleh juga lebih teratur dan dalam jumlah yang lebih besar.

\section{B. Pembahasan Hasil Analisis Multivariat}

Analisi multivariat dengan regresi logistik dari tiga Kabupaten yaitu Sijunjung, Padang Pariaman Dan Pasaman Barat didapatkan variabel yang paling dominan yaitu variabel ekonomi keluarga.

Tingkat pendapatan akan menentukan jenis dan ragam makanan yang akan di beli dengan uang tambahan. Keluarga dengan penghasilan rendah akan menggunakan sebagian besar dari keuangannya untuk membeli makanan dan bahan makanan. Penghasilan yang rendah berarti rendah pula jumlah uang yang akan di belanjakan untuk makanan sehingga bahan makanan yang dibeli untuk keluarga tersebut tidak mencukupi untuk mendapat dan memelihara kesehatan seluruh keluarga. Apabila pendapatan meningkat, maka akan terjadi perubahan dalam susunan makanan, karena peningkatan pendapatan tersebut memungkinkan mereka mampu membeli pangan yang berkualitas dan berkuantitas lebih baik. Namun perlu diketahui, bahwa pengeluaran uang yang lebih banyak untuk pangan tidak menjamin lebih beragamnya konsumsi pangan. Kadang perubahan utama yang terjadi dalam kebiasaan makan yaitu pangan yang dimakan itu lebih mahal. Asupan makanan yang tidak cukup baik segi jumlah maupun kualitas dalam jangka lama akan menyebabkan terjadinya gangguan gizi. Keadaan kurang gizi akan mengurangi daya tahan tubuh terhadap penyakit, memengaruhi tingkat kecerdasan dan prestasi belajar, produktivitas kerja dan pendapatan. Pengukuran ekonomi keluarga dengan status gizi yaitu: (Andriyani \& Wirjatmmadi, 2014).

Dalam penelitian alamsyah, et al (2015), dengan judul penelitian beberapa faktor risiko gizi kurang dan gizi buruk pada balita 12 - 59 bulan mengenai pendapatan keluarga rendah $(\mathrm{OR}=4,20$ $\mathrm{P}=0,020)$, pendapatan keluarga rendah buruk terbukti sebagai faktor risiko kejadian gizi kurang dan gizi buruk pada balita dengan OR 4,20 artinya ibu yang mempunyai balita gizi kurang dan gizi buruk mempunyai risiko 4 kali untuk menderita gizi kurang dan gizi buruk bila dibandingkan dengan ibu yang mempunyai balita yang gizi baik di karnakan tak kecukupan dalam menyediakan makanan (Andriyani \& Wirjatmmadi, 2014).

Namun dalam penelitian Rahma, et al (2016) dengan penelitian perbedaan sosial ekonomi dan pengetahuan gizi ibu Balita gizi kurang dan gizi normal dengan hasil uji statistik independent $t$-test menunjukkan bahwa tidak ada perbedaan pendapatan 
keluarga antara balita gizi kurang dan gizi normal $(p=0,189)$.

Menurut peneliti ekonomi keluarga yang rendah akan sangat mempengaruhi daya beli bahan pangan yang bergizi untuk balita ataupun keluarga. Adapun bahan pokok yang sederhana dan murah bila ibu yang tidak memliki pengetahuan mengkonsumsi makanan yang sederhana, bergizi dan sehat akan menjadi hal yang sulit untuk di dapat oleh balita.

\section{KESIMPULAN}

Dari hasil penelitian faktor yang paling dominan yang mempengaruhi kejadian Composite Index of Anthropometric Failure (CIAF) dari tiga Kabupaten Sijunjung, Padang Pariaman dan Pasaman Barat ekonomi keluarga dengan $\mathrm{P}$ value 0,000 ( OR 10,503).

\section{UCAPAN TERIMAKASIH}

Terimakasih di ucapkan untuk kepada Dinas Kesehatan Provinsi Sumatera Barat dan Dinas Provinsi Kabupaten yang telah membantu dalam hal data-data pendukung yang diperlukan kemudian ucapan terimakasih pada Sekolah tinggi ilmu kesehatan fort de kock dalam penyelesaian penelitian ini.

\section{REFERENSI}

Andriyani \& wirjatmadi. 2014. Gizi dan kesehatan balita. Jakarta

Alamsyah, Dedi, et all. 2015. Beberapa faktor risiko gizi kurang Dan gizi buruk pada balita 12 - 59 bulan. jurnal vokasi Kesehatan, Volume I Nomor 5 September 2015, hlm. 131 - 135

Arum, Rizki et al. 2017. Faktor-faktor yang berhubungan dengan terjadinya gizi kurang pada anak balita usia 24-59 bulan. Juli 2017

Bapenas, 2011. Rencanan aksi nasional pangan dan gizi 2011-2015. Jakarta: Kencana
Bapenas, 2013. Kerangka Kebijakan Gerakan Nasional Percepatan Perbaikan Gizi dalam Rangka Seribu Hari Pertama Kehidupan (Gerakan 1000 HPK. Jakarta

Dinas Kesehatan Sumatera Barat. 2016. Profil Dinas Kesehatan Provinsi Sumatera Barat Tahun 2016. Sumatera Barat

Dinas kesehatan. 2016. Buku saku pematauan gizi tahun 2016

Endris, Asefa, \& Dube. 2017. Prevalence of Malnutrition and Associated Factors among Children in Rural Ethiopia. Volume 2017, Article ID 6587853, 6 pages

Goswami. 2016. Prevalence of UnderNutrition Measured by Composite Index of Anthropometric Failure (CIAF) Among the Bhumij Children of Northern Odisha, India. Januari-april 2016.

Jannah, Miftakhul dan Maesaroh. 2014. judul hubungan tingkat pendidikan ibu dengan status gizi balita di posyandu bangunsari semin gunung kidul

Kemenkes. 2017. Buku Saku Pemantauan Status gizi dan Indikator Kinerja Gizi Tahun 2016. Jakarta

Kemenkes. 2017. Buku Saku Pemantauan Status gizi Tahun 2017. Jakarta

Kemenkes. 2017. Pedoman Pelaksanaan Pemantauan Gizi. Jakarta

Kramsapi1 et al, Indeks Komposit Kegagalan Antropometri (Ciaf) Di Antara AnakAnak Suku Pra-Sekolah (2-5 Tahun) Suku Assam (India). Januari 2018

Lusia, et al. 2017. Hubungan antara praktik pemberian makan keluarga dengan berat badan pada anak usia 2-5 tahun di posyandu mawar kelurahan tlogomas kecamatan lowokwaru kota malang. Nursing News Volume 2, Nomor 2, 2017

M, Ardian. C., Subagio, H. W., \& Margawati, A. (2016). Determinan kejadian 
stunting pada bayi usia 6 bulan di kota semarang. Jurnal Gizi Indonesia.

Nandy, S et al, 2005. Poverty, Child Undernutrition and Morbidity : New Evidenc From India. Bull. WHO, 83 : 210-216

Notoatmodjo, Soekidjo. 2012. Metodologi Penelitian Kesehatan. Jakarta: Rineka Cipta

Oktovina et al. 2015. pengaruh pemberian makanan tambahan biskuit dan bolu tepung tempe terhadap peningkatan berat badan dan tinggi badan pada balita gizi kurang tahun 2015

Perdani, Zulia Putri, et al. 2016. Hubungan pemberian makanan dengan status gizi anak usia 3-5 tahun di pos gizi tegal kunir lor mauk. jurnal kesehatan januari 2016.

Rahma, Amelinda Calida \& Siti Rahayu Nadhiroh. 2016. Perbedaan sosial ekonomi dan pengetahuan gizi ibu
Balita gizi kurang dan gizi normal. Media Gizi Indonesia, Vol. 11, No. 1 Januari-Juni 2016: hlm. 55-60

Renstra. 2015. Rencana Strategis Kementrian Kesehatan Tahun 2015-2019. Jakarta : Sekretariat Jendral

Riskesdas. 2013. Riset Kesehatan Dasar Tahun 2013. Jakarta

Supariasa, dkk. 2002. Penilaian status gizi. Jakarta: penerbit buku kedokteran

UNICEF, WHO, World Bank Group. 2017. Levels and Trend in Child Malnutrition

Widodo, et all. 2017. Skor pola pangan harapan dan hubungannya dengan status gizi anak usia 0,5 - 12 tahun di indonesia. Penelitian gizi dan makanan, desember 2017 vol. 40 (2): 63-75

WHO. 2016. World Health Statistic Monitoring Health for The SDGs

WHO.2017.Malnutrion.hhtp://www.who.int/m ediacentre/factsheets/malnutrion/en 